\title{
Performance evaluation of VolP technology in an extended service set, in concordance with IEEE 802.11g
}

Marcelo David Núñez Cuadrado / mdnunez@espe.edu.ec

Carlos Andres Jativa Huilcapi / cajativa1@espe.edu.ec

Román Alcides Lara Cueva / ralara@espe.edu.ec

Universidad de las Fuerzas Armadas - ESPE

Sangolquí, Ecuador

ABSTRACT In this paper, we evaluate the performance in function of the metrics associated to Quality of Service [QoS] and Quality of user Experience [QoE] in an experimental way in the VoIP service for G.711 and G.729 códecs. This was performed over an extended service set based on Wi-Fi technology in concordance with IEEE 802.1 $1 \mathrm{~g}$ standard using embedded systems. QoS related metrics are obtained by using the intrusive traffic injection technique. In addition, we assessed the QoE using the MOSc [Mean Opinion Score conversational] analysis. The best results were obtained for G.729, reaching up to 25 simultaneous injections with optimal delay, jitter and packet loss values according to the ITU-T recommendation for VoIP. However, the G.711 codec presented a better throughput. On the other hand, QoE evaluation indicates a slight superiority of G.729 in the MOSc appreciation. Finally, we conclude that packet loss and delay are the most influential metrics in VoIP service degradation.

KEYWORDS Alix; ESS; IEEE 802.11g; MOS; QoE; QoS; VoIP.

Evaluación del desempeño de la tecnología VolP en un set de servicio extendido, en concordancia con IEEE 802.11g

RESUMEN En este artículo se evalúa experimentalmente el desempeño en función de las métricas asociadas a Calidad de Servicio [QoS] y Calidad de Experiencia de Usuario [QoE] en el servicio de voz sobre IP [VoIP] para los códecs G.711 y G.729, sobre un set de servicio extendido con tecnología Wi-Fi, en concordancia con el estándar IEEE 802.11 g, implementado mediante sistemas embebidos. Las métricas de QoS se obtienen mediante la técnica intrusiva de inyección de tráfico, adicionalmente se evalúa la QoE por medio del análisis MOSc [Mean Opinion Score conversational). Los mejores resultados fueron obtenidos por el códec G.729, que alcanzó hasta 25 flujos concurrentes con valores óptimos de retardo, jitter y pérdida de paquetes según la recomendación de la ITU-T para VoIP. Sin embargo, G.711 presentó un mejor throughput. Por otro lado, la evaluación de QoE señala una ligera superioridad de G.729 en la valoración MOSc. Finalmente, se concluye que la pérdida de paquetes y el retardo son las métricas más influyentes en la degradación del servicio de VoIP.

PALABRAS CLAVE Alix; ESS; IEEE 802.11g; MOS; QoE; QoS; VoIP.
Avaliação do desempenho da tecnologia VolP em um conjunto de serviços estendido de acordo com o IEEE 802.11g

RESUMO O desempenho é avaliado experimentalmente com base nas métricas associadas à Qualidade de Serviço [QoS] e à Qualidade de Experiência do Usuário [QoE] no serviço de voz sobre IP [VoIP] para os codecs G.711 e G.729, em um conjunto de serviço estendido com tecnologia Wi-Fi, de acordo com o padrão IEEE $802.11 \mathrm{~g}$, implementado através de sistemas embarcados. As métricas de QoS são obtidas através da técnica intrusiva de injeção de tráfego, além disso, a QoE é avaliada por meio da análise MOSc (Mean Opinion Score conversational). Os melhores resultados foram obtidos pelo codec G.729, que atingiu até 25 fluxos simultâneos com valores ótimos de atraso, jitter e perda de pacotes de acordo com a recomendação ITU-T para VoIP. No entanto, o G.711 apresentou melhor throughput. Por outro lado, a avaliação da QoE indica uma ligeira superioridade do G.729 na avaliação MOSc. Finalmente, conclui-se que a perda de pacotes e o atraso são as métricas mais influentes na degradação do serviço VoIP.

PALAVRAS-CHAVE Alix; ESS; IEEE 802.11g; MOS; QoE; QoS; VoIP. 


\section{Introduction}

The need to provide reliable, secure, low-cost, and real-time voice services is a fundamental factor in the last-generation communications (Ramírez, 2013). The analogic centrals are in the past and the current trend is to implement solutions based on data networks to provide voice services over the Internet protocol $[\mathrm{VoIP}]$ through the packet switching and the use of voice protocols and codecs to manage the communication (Kolahi, Shah \& Joseph, 2012). As per the Frost \& Sullivan consulting firm, it is expected that the VoIP incomes grow to a $21.5 \%$ annual rate until 2020, while their users will potentially grow in a $18.1 \%$ rate (Frost \& Sullivan, 2017).

One of the aspects with broader discussion within VoIP is the quality of service [QoS], which is defined as the capacity the network has in order to manage the traffic demand as per the service class to satisfy the user expectations (Vesga-Ferreira, Granados-Acuña \& Vesga-Barrera, 2016). On the other hand, the quality perceived by the user is a concept known as quality of user experience [QoE], quantifiable based on the ITU-T Rec. P.800, where a subjective method that involves the execution of tests to the survey respondents to assess the perception in the transmission quality is described. This suggests that this parameter is based on the users' opinion regarding the studied system. The result of this test is a numeric value, called mean opinion score [MOS], that represents the QoE level of the service (Cano \& Cerdan, 2012).

In addition, the need to use economic, flexible, and low-energy consumption devices motivate to work with embedded systems, making the Alix.3d3 card (PC Engines, 2013) the suitable one, since its reduced size and large potential plus its popularity in the open source market. This card can operate as a Linux security server, wireless router, firewall, as a specific network device, repeater, etc., (PC Engines, 2013). Section II of this document presents a broader explanation of the topic this project addressed.

The literature review performed a priori showed that the found research works do not evaluate the performance of the VoIP service in an extended service set [ESS] implemented with embedded systems, which is the result of the union of two basic service sets [BSS] connected through a distribution system (Coleman \& Westcott, 2009). Consequently, the objective of our work is to assess the performance of an ESS in accordance with the IEEE 802.11g standard in function of the QoS and QoE associated metrics for the VoIP service, implemented in an outdoors place of the campus in the Universidad de las Fuerzas Armadas [ESPE] through embedded

\section{Introducción}

La necesidad de brindar un servicio de voz que sea confiable, seguro, de bajo costo y en tiempo real es un factor fundamental en las comunicaciones de última generación (Ramírez, 2013). Las centrales analógicas quedaron en el pasado y, por esta razón, la tendencia actual es implementar soluciones basadas en redes de datos para proporcionar servicios de voz sobre el protocolo de Internet [VoIP, Voice over Internet Protocol] mediante la conmutación de paquetes y el uso de protocolos de voz y códecs de audio para gestionar la comunicación (Kolahi, Shah \& Joseph, 2012). Según la consultora Frost \& Sullivan (2017) se espera que los ingresos de VoIP crezcan a una tasa anual compuesta del 21,5\% hasta 2020, mientras que, a su vez, los usuarios lo hagan al 18,1\%. Uno de los aspectos de mayor discusión dentro de VoIP ha sido la calidad de servicio [QoS, Quality of Service], la cual se define como la capacidad que tiene una red para administrar la demanda de tráfico según la clase de servicio, con el fin de satisfacer las expectativas del usuario (Vesga-Ferreira, Granados-Acuña \& Vesga-Barrera, 2016). Por otro lado, la calidad percibida por el usuario es un concepto conocido como calidad de experiencia del usuario [QoE, Quality of user Experience], la misma que puede ser medida con base en la ITU-T Rec. P.800, la cual describe un método subjetivo que involucra la realización de pruebas a los encuestados para evaluar la percepción de la calidad de la transmisión. Lo anterior sugiere que se basa en la opinión de los usuarios sobre el sistema en estudio. El resultado de esta prueba es un valor numérico, denominado Mean Opinion Score [MOS], que representa el nivel de QoE del servicio (Cano \& Cerdan, 2012). Por otra parte, la necesidad de utilizar un equipo económico, flexible y con bajo consumo de energía, impulsa a trabajar con sistemas embebidos, haciendo de la tarjeta Alix.3d3 (PG Engines, 2013) la ideal, puesto que se destaca por su reducido tamaño y potencial, además de su alta popularidad en el mercado de código abierto integrado ya que puede trabajar como servidor de seguridad de Linux, enrutador inalámbrico, cortafuegos, dispositivo de red específico, repetidor, etc., (PG Engines, 2013). En la sección II de este documento, se profundiza de mejor manera sobre la temática que abarca el presente proyecto.

En este contexto, las investigaciones mencionadas no evalúan el desempeño del servicio de VoIP en un set de servicio extendido [ESS, Extended Service Set] implementado con sistemas embebidos, el cual resulta de unir dos o más BSS [Basic Service Set] conectados por un sistema de distribución (Coleman \& Westcott, 2009). Por lo tanto, el objetivo del presente trabajo es evaluar el desempeño de un ESS en concordancia con el estándar IEEE 802.1 lg, en función de las métricas asociadas a QoS y QoE del servicio de VoIP implementado en el ambiente exterior del campus de la Universidad de las Fuerzas Armadas [ESPE] mediante sistemas embebidos, para lo cual se emplea una técnica intrusiva de inyección de tráfico bajo el protocolo UDP con el fin de obtener las métricas asociadas al QoS como throughput $(\eta), \delta$, P L y jitter. Por otra parte, la evaluación de QoE se realiza a través del método 
subjetivo denominado prueba de opinión sobre la conversación donde se califica la calidad de cada llamada en la escala ACR [Absolute Category Rating], de acuerdo con la ITU-T Rec. P.800.

El presente artículo se estructura de la siguiente manera: en la sección II se muestra un estudio del estado del arte; en la sección III se presentan los equipos y programas utilizados para el despliegue del ESS, se especifican los diferentes escenarios de pruebas y se describe el método intrusivo de inyección de tráfico para la obtención de las métricas asociadas al QoS, al igual que el método MOS para la prueba de opinión sobre la conversación; en la sección IV se presenta el análisis comparativo de las métricas de interés en los diferentes escenarios de pruebas; y finalmente, en la sección $\mathrm{V}$ se discuten los resultados obtenidos, se contrastan con trabajos previos, y se exponen las conclusiones y trabajos futuros.

\section{Estado del arte}

Existen trabajos relacionados al análisis de QoS para VoIP en redes inalámbricas en concordancia con el estándar IEEE 802.11, por ejemplo: Keegan \& Davis (2006) realizaron el análisis experimental de una red WLAN [Wireless Local Area Network) basada en IEEE 802.11b para VoIP, donde se presenta que, debido a la operación del mecanismo de control de acceso al medio [MAC, Media Access Control), el punto de acceso [AP, Access Point) actúa como cuello de botella para todo el tráfico dirigido a las estaciones inalámbricas, por lo que se pueden producir retardos (delays) ( $\boldsymbol{\delta}$ ) significativos en los paquetes VoIP, lo que resulta en una pobre percepción de QoS. En consecuencia, el rendimiento del enlace descendente del AP es el componente crítico en la determinación de la capacidad de llamadas VoIP. Del mismo modo, Agredo \& Gaviria (2006) evalúan de forma experimental la capacidad del estándar IEEE 802.1 lb para soporte de VoIP de dos maneras distintas: usando el generador de tráfico D-ITG [Distributed Internet Traffic Generator] y mediante la generación de llamadas reales a través del software para PBX-VoIP Asterisk, y concluyen que los resultados de $\boldsymbol{\delta}$, jitter y paquetes perdidos [PL, Packet Loss] obtenidos por ambos métodos fueron en general coincidentes, tanto para el códec G.711, como para el G.729. Además, pese a que el ancho de banda utilizado por el códec G.729 es la tercera parte del G.711, el primero presenta una ventaja de apenas el $14 \%$ en cuanto a la capacidad de llamadas simultáneas permitidas, por lo que en una WLAN la principal limitante es la contienda por el acceso al medio. Concluyen también que no es posible calcular la capacidad de canales de VoIP en una red IEEE 802.1 lb con una simple división entre el ancho de banda total para el ancho de banda por canal, por lo que se deben considerar más factores como el número de paquetes por segundo o el consumo de máquina costo computacional que puede tenerse con la codificación de voz.

Dini, Font-Bach y Mangues-Bafalluy (2008) realizan un análisis experimental del soporte de la calidad de llamada VoIP bajo el estándar IEEE 802.11 donde relacionan el systems. Our goal was to use a traffic injection intrusive technique under the UDP protocol to gather the QoS associated metrics such as throughput ( $\eta), \boldsymbol{\delta}$, packet loss [PL] and jitter. Conversely, the QoE evaluation was performed through the subjective method called opinion test regarding the conversation, where the quality of the call in the absolute category rating [ACR] scale is assessed as per the ITU-T Rec. P.800.

This work is structured as follows: Section II presents a brief study of the state of the art, Section III present the equipment and software employed for the ESS deployment, where we specify the different test scenarios and we describe the traffic injection intrusive method for the gathering of QoS metrics. The MOS method for the opinion test is also described here. Section IV presents the comparative analysis of the interested metrics in the different test scenarios and Section $\mathrm{V}$ concludes this document by presenting the obtained results, we contrast with previous works, and we expose our conclusions and proposed future works.

\section{State of the art}

There are works related with the QoS analysis for VoIP in wireless networks in accordance with the IEEE 802.11 standard, e.g., Keegan \& Davis (2006) performed the experimental analysis of a wireless local area network [WLAN] based on IEEE 802.11b for VoIP, where due to the media access control [MAC] mechanism, the access point [AP] acts as a bottleneck for all the traffic pointed to the wireless stations; hence, significative delays $(\boldsymbol{\delta})$ in the packets can arise. This entails a poor QoS perception and, in consequence, the performance of the AP downlink is the critical component in the determination of the VoIP calls capacity. Likewise, Agredo \& Gaviria (2006) evaluate experimentally the capacity of the IEEE 802.1 lb for VoIP support in two ways: by using the distributed internet traffic generator [D-ITG] traffic generator and through the generation of real calls using the Asterisk VoIP-PBX. They conclude that the $\boldsymbol{\delta}$, jitter, and packet loss values obtained from both methods were, in general, similar for both G.711 and G.729 codecs. Furthermore, although the bandwidth employed by the G.729 codec is one third of the one used by the G.711, the first presented only an advantage of $14 \%$ regarding the maximum allowed simultaneous calls; since, in a WLAN the main issue is the dispute for the access to the medium. The authors also conclude that it is not possible to calculate the VoIP channel capacity in an IEEE 802.11b network with a simple division between the total bandwidth and the bandwidth per channel; more factors must be considered such as the number of packets per second or the computational cost that the voice coding entails. 
Dini, Font-Bach \& Mangues-Bafalluy (2008) performed an experimental analysis of the support in the VoIP call quality under the 802.11 standard, where they relate the E-Model with the QoS metrics to find the optimum operation point for VoIP in a WLAN. They conclude that the metric with the highest influence in the degradation of the call quality is the PL due to the buffer overflowing in the transmitting stations. Further, 98\% of the packet loss is in the downlink generally. As a consequence, the $\mathrm{AP}$ transmission buffer is the limiting factor. Villacís, Acosta \& Lara (2013) present the capacities of the Alix 2d2 card for VoIP applications using an Asterisk embedded server and they reference the performance analysis of the VoIP services in Wi-Fi systems. They analyze the SIP and IAX protocols together with the GSM, G.711 U/A, Speex, and G.726 codecs according to the IEEE 802.11b and IEEE 802.11g standards, showing the viability to implement VoIP in small processors with a low RAM consumption. Finally, Oliveira \& Siqueira (2006) analyze the VoIP calls capacity in an ad hoc IEEE 802.11 network, where each node directly communicates with the others, becoming it into a more economical solution than a traditional telecommunications scenario, which might reach remote communities.

\section{Methodology}

The employed network topology is displayed in FigurE 1, where each location has a device with an Alix.3d3 card. This model has a AMD Geode LX processor running at $500 \mathrm{MHz}$ and it also has $256 \mathrm{MB}$ of SDRAM, a socket for compact flash memories up to 4 GB that operates as a hard disk, and two mini-PCI sockets for wireless radio cards. In
E-Model con las métricas de QoS, con el fin de encontrar el punto de trabajo óptimo para VoIP en una WLAN. Se concluye que la métrica con mayor influencia en la degradación de la calidad de la llamada es el PL, debido al desbordamiento del buffer de las estaciones transmisoras, además de que en particular, el 98\% de PL se encuentra en el enlace descendente. En consecuencia, el buffer de transmisión del AP es el factor limitante. Villacís, Acosta y Lara (2013) presentan las capacidades de la tarjeta Alix 2d2 para el manejo de VoIP con un servidor Asterisk embebido, además hacen referencia al análisis de desempeño de servicios de VoIP sobre sistemas basados en Wi-Fi [Wireless Fidelity] y analizan los protocolos SIP e IAX junto con los códecs GSM, G.711 U/A, Speex, y G.726, en concordancia con los estándares IEEE 802.11b e IEEE $802.1 \mathrm{~g}$, mostrando la viabilidad de implementar VoIP en pequeños procesadores con un bajo consumo de RAM. Finalmente, Oliveira \& Siqueira (2006) analizan la capacidad de las llamadas de VoIP sobre una red ad hoc IEEE 802.11, donde cada nodo se comunica directamente entre sí, convirtiéndose en una solución más económica que un escenario tradicional de telecomunicaciones, lo que permite llegar con el servicio a comunidades remotas.

\section{Metodología}

La topología de red utilizada se aprecia en la Figura 1, en donde cada emplazamiento dispone de un dispositivo con tarjeta Alix.3d3. Este modelo de tarjeta posee un procesador AMD Geode LX de 500 MHz y 256 MB de SDRAM, un socket para memorias tipo compact flash de 4GB que trabaja como disco duro y dos sockets mini-PCI para tarjetas de radio inalámbricas. En el socket 1 se utiliza una tarjeta Winstron-CM9 (Winstron Neweb Corp., 2011) a 2.4 GHz, en concordancia con IEEE 802.11g, configurada como AP en el canal 11, mientras que para el socket 2 se usa la tarjeta Ubiquiti-SR2 (Ubiquiti Networks, 2013) a 2.4 GHz, en concordancia con IEEE $802.1 \mathrm{~g}$, configurada en modo ad hoc en

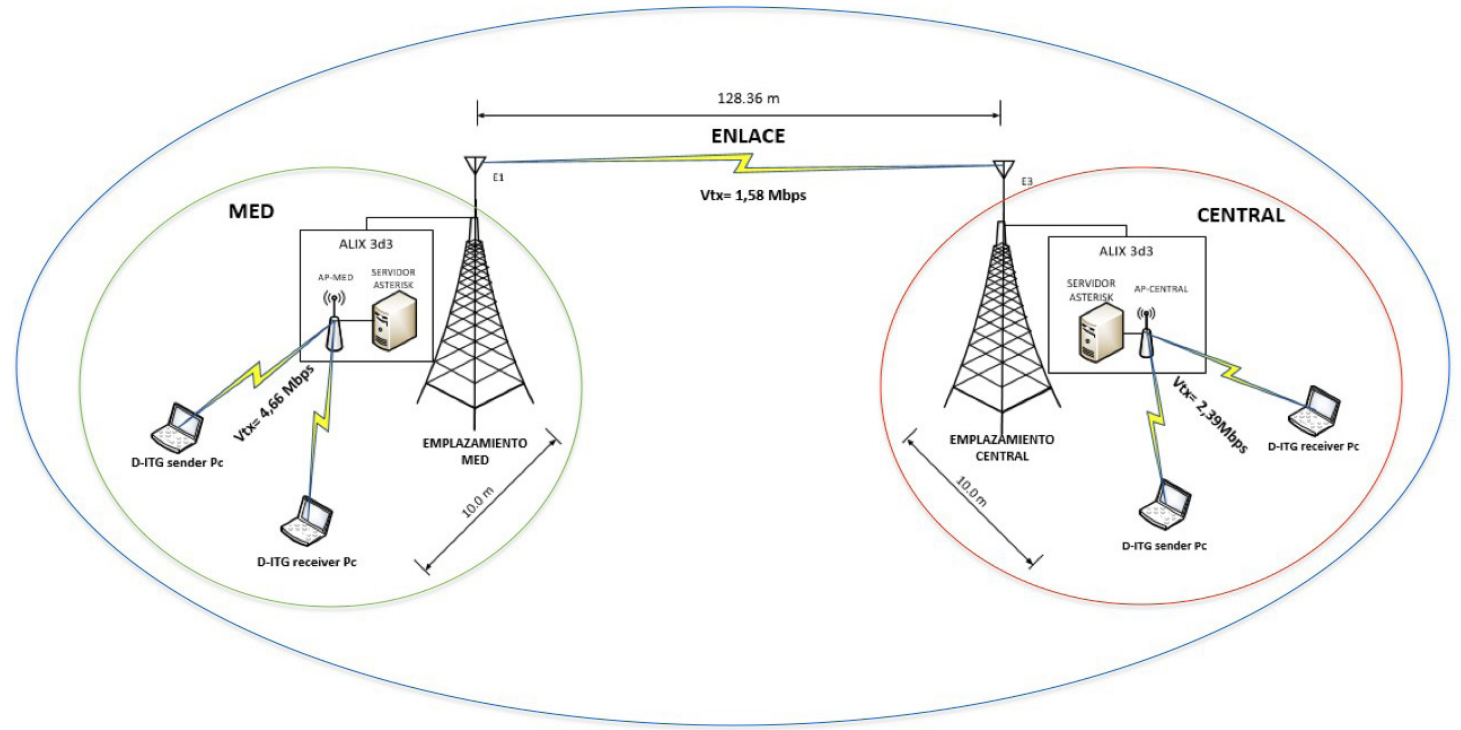

Figure 1. Network topology for QoS tests / Topología de red para Pruebas de QoS 
Table 1. Features of the employed PCs for QoS tests / Características de PCs utilizadas para pruebas de QoS

\begin{tabular}{lll}
\hline $\begin{array}{l}\text { Features / } \\
\text { Características }\end{array}$ & PG1 & PC2 \\
\hline $\begin{array}{l}\text { Processor / Pro- } \\
\text { cesador }\end{array}$ & Intel core i5 & Intel core i7 \\
SDRAM & $8 \mathrm{~GB}$ & $6 \mathrm{~GB}$ \\
$\begin{array}{l}\text { Wireless card / } \\
\text { Tarjeta inalámbrica }\end{array}$ & Broadcom & Intel Centrino \\
$\begin{array}{l}\text { Standard WiFi } \\
\text { Function / }\end{array}$ & $\mathrm{a} / \mathrm{b} / \mathrm{g} / \mathrm{n} / \mathrm{ac}$ & $\mathrm{b} / \mathrm{g} / \mathrm{n}$ \\
Función & Transmisor & Receptor \\
\hline
\end{tabular}

el canal 6 para establecer el enlace entre emplazamientos. Ambos modelos de tarjetas de radio poseen chip Atheros y conectores U-FL Ultra-miniature, desde donde se conecta una antena omnidireccional de $2.4 \mathrm{GHz}$ con $3 \mathrm{dBi}$ de ganancia para el AP y una antena tipo grilla (QPCOM, 2011) de $2.4 \mathrm{GHz}$ con una ganancia de $24 \mathrm{dBi}$ para el enlace ad hoc. La potencia de transmisión [PTX] y la tasa promedio de bits o bitrate de la tarjeta inalámbrica CM9 fue configurada en modo AUTO, debido que a medida que aumenta la distancia entre el equipo terminal y el AP, el bitrate debe reducirse para así mantener una conectividad confiable (Geier, 2010), además se debe garantizar una buena relación señal a ruido [SNR, Signal to Noise Ratio]. Por otro lado, en la tarjeta SR2 se definió una PTX de $26 \mathrm{dBm}$ y un bitrate de $6 \mathrm{Mbps}$ puesto que así se garantiza una conectividad permanente del enlace principal.

El sistema operativo utilizado en las tarjetas Alix.3d3 es Voyage-One 0.8.5 de Linux, se seleccionó esta versión debido a que es de libre distribución, funciona como servidor y provee funcionalidades de VoIP mediante el paquete integrado Asterisk 1.8.12.0 rc3 (Voyage Design and Consultants, 2013). La capacidad del enlace se evalúa según los parámetros asociados a QoS mediante la técnica intrusiva de inyección de tráfico utilizando el software D-ITG, que posee capacidad de generar tráfico de VoIP con tres códecs de audio: G.711, G.723 Y G.729 (Avallone, Guadagno, Emma, \& Ventre, 2004). La evaluación de QoE se realiza con la aplicación gratuita de softphone para llamadas de VoIP sobre WiFi o 3G llamada Zoiper (Zoiper, 2017).

Como equipos terminales se utilizaron dos computadoras portátiles con sistema operativo Linux-Ubuntu 15.04 (Canonical, 2016), además se utilizaron smartphones de varios modelos y marcas, las características de los PC se muestran en la TABLA 1.

El escenario donde se implementó la topología de red mostrada en la Figura 1 es la sede matriz del Universitario de la ESPE, ubicada en Sangolquí (Pichincha, Ecuador) con coordenadas $\left(0^{\circ} 18^{\prime} 52.1352^{\prime \prime} \mathrm{S}, 78^{\circ} 26^{\prime} 37.5216^{\prime \prime} \mathrm{O}\right)$, donde se instalaron los equipos en las terrazas de sus edificios Central y MED respectivamente, con una distancia entre emplaza- socket 1, we used a Winstron-CM9 card (Winstron Neweb Corp., 2011) running at $2.4 \mathrm{GHz}$ in accordance with IEEE 802.11g, configured as an AP in channel 11. Whilst socket 2 uses the Ubiquiti-SR2 card (Ubiquiti Networks, 2013) also at $2.4 \mathrm{GHz}$ in accordance with IEEE 802.11g configured in ad hoc mode in channel 6; this, to establish the link between locations. Both card models have Atheros chips and U-FL ultra-miniature connectors, from where we connected an omnidirectional antenna working at $2.4 \mathrm{GHz}$ with a gain of $3 \mathrm{dBi}$ for the AP and a grid antenna (QPCOM, 2011) at 2.4 $\mathrm{GHz}$ with a gain of $24 \mathrm{dBi}$ for the ad hoc link.

The transmission power [PTX] and the average bitrate of the CM9 wireless card were set to AUTO, due to the fact that when the distance between the terminal and the AP grows, the bitrate must be reduced to maintain a stable connection (Geier, 2010). Furthermore, a good signal to noise ratio [SNR] should be guaranteed in the links. On the other hand, in the SR2 card we defined a PTX of $26 \mathrm{dBm}$ and a $6 \mathrm{Mbps}$ bitrate, since that way we guarantee the connectivity of the main link.

The employed operating system in the Alix3.d3 cards is the so-called Voyage-One 0.8.5, a Linux distro. We selected this version because it has free distribution, it works as a server, and it provides VoIP functionalities through the Asterisk 1.8 integrated packet (Voyage Design and Consultants, 2013). The link capacity was assessed as per the QoS associated parameters through the traffic injection intrusive technique using the D-ITG software. This latter has the ability to generate VoIP traffic using three audio codecs: G.711, G.723, and G.729 (Avallone, Guadagno, Emma, \& Ventre, 2004). The QoE evaluation was performed with the freely accessible application for VoIP calls over Wi-Fi or cellular networks called Zoiper (Zoiper, 2017).

As remote-end computers, we employed two laptops with Ubuntu 15.04 operating system (Canonical, 2016), further, we employed smartphones of several brands and models. The PCs features are shown in TABLE 1.

The scenario where the network topology displayed in FIGURE 1 was implemented is the headquarters of the Universitario of the ESPE, located in Sangolquí (Pichincha, Ecuador). The exact coordinates of the place are $\left(0^{\circ} 18^{\prime} 52.1352^{\prime \prime}\right.$ S, 78²6'37.5216" W). Here, we installed the equipment in the rooftops of the Central and MED buildings, respectively, with a distance between locations of about 128 meters. By using the Wi-Fi Analyzer application (Farproc, 2017), we spotted 5 interfering networks in the MED location operating in the same wireless channel; whilst, in Central, 7 interfer- 
ing networks were spotted plus several operating antennas: a satellite dish, a drum antenna, and several TV antennas. Furthermore, a generator and two fans are in that rooftop, elements that might degrade the link quality due to the noise generation (Evans, 1989).

On the other hand, the signal intensity from the radios configured as $\mathrm{AP}$ is in the range of -47 to $-52 \mathrm{dBm}$ and -52 to $-67 \mathrm{dBm}$ for the MED and Central locations, respectively. In order to perform the performance analysis, we considered another location called Enlace. The MED and Central locations are configured as infrastructure mode (i.e., BSS) and the new Enlace was configured in ad hoc or independent basic service set [IBSS] mode. The sum of these elements makes an ESS and in each one of them we performed the respective QoS and QoE tests.

The test stage was split in two phases. The first one consisted of the evaluation of the QoS metrics, for that, we defined a fixed position of the equipment 10 meters separated of the tower base. Firstly, we defined the real channel capacity on each sub-scenario, the procedure was to flood the channel with packets sent through the D-ITG software between the transceiver and receiver PCs, as FigurE 1 shows. After that, we modified the transmission rate $[\mathrm{VTx}]$ until the PL values are lower than $1 \%$. TABLE 2 presents the injected values on each sub-scenario. Once the identification of the VTx parameter is completed, we performed 5 more injections (I3I7) to reduce the uncertainty and the root mean error (Lara, Fernández \& Morales, 2016). The synchronization of the clock signal in the PGs is an important aspect to ensure a correct value of $\boldsymbol{\delta}$. Consequently, we created a network time protocol [NTP] server as Mills (1991) indicates.

After that, we determined the maximum number of simultaneous calls that the wireless network handles. For that, we did VoIP traffic multi-flow injections, where each flow emulates a real session. The injection time lasted 90 seconds (IBM Knowledge Center, 2011) and we increased the number of flows progressively until having an elevated PL value. The ITU-T Rec. G. 114 considers that, in order to guarantee a good VoIP call quality, the maximum $\boldsymbol{\delta}$ value in one way should not be larger than $150 \mathrm{~ms}$ and regarding PL, it must not be larger than 1\% (Dialogic Corporation, 2007). The average jitter in one way should be under $30 \mathrm{~ms}$ (Hattingh \& Szigeti, 2004). This procedure was repeated with the G.711 and G.729 codecs using two samples on all the three sub-scenarios. The D-ITG configuration parameters are shown in TABLE 3. mientos de aproximadamente $128 \mathrm{~m}$. Con ayuda de la aplicación WiFi Analyzer (Farproc, 2017) se c-ontabilizó un total de cinco redes interferentes en el emplazamiento MED operando en el mismo canal, mientras que en Central existieron siete redes interferentes. Además, en Central existen varias antenas operando: una antena satelital, una antena tipo tambor y varias antenas de TV, así como un generador y dos ventiladores, elementos que degradan el rendimiento debido a la generación de ruido (Evans \& Britain, 1989). Por otro lado, la intensidad de la señal proveniente de los radios configurados como AP se encuentra en el rango de -47 a $-52 \mathrm{dBm}$ y -52 a -67 dBm en los emplazamientos MED y Central, respectivamente. Para realizar una comparativa de desempeño se dividió en tres subescenarios: MED, Central y Enlace, los dos primeros se configuraron en modo infraestructura o BSS [Basic Service Set] y el tercero en modo ad hoc o IBSS [Independent Basic Service Set], conformando así un ESS. En cada uno de ellos se realizaron las pruebas respectivas de QoS y QoE.

La etapa de pruebas se dividió en dos fases. La primera fase consistió en la evaluación de las métricas de QoS, para ello se definió una posición fija de los equipos terminales a una distancia de $10 \mathrm{~m}$ desde la base de la torre. En primera instancia se definió la capacidad real del canal en cada subescenario, el procedimiento consistió en inundar el canal con paquetes de datos enviados a través del software D-ITG entre los PC transmisor y receptor, como se muestra en la Figura 1, e ir variando la tasa de transmisión [VTx] hasta que el PL sea menor al 1\%. La TABLA 2 muestra los valores inyectados en cada subescenario. Una vez identificada la VTx máxima, se realizaron cinco inyecciones (I3-I7) para reducir la incertidumbre y el error cuadrático medio (Lara, Fernández \& Morales, 2016). La sincronización de la señal de reloj de los PC es un aspecto importante para garantizar un correcto valor de $\boldsymbol{\delta}$; por consiguiente, se creó un servidor NTP [Network Time Protocol] tal como se indica en Mills (1991).

Posteriormente se determinó el número máximo de llamadas simultáneas que soporta la red inalámbrica, para lo cual se procedió a realizar inyecciones de tráfico VoIP multiflujo, donde cada flujo emula una sesión real. El tiempo de duración de cada inyección fue de 90 segundos (IBM Knowledge Center, 2011). El número de flujos fue incrementado progresivamente hasta tener un PL elevado. La ITU-T Rec. G.114 considera que para garantizar una buena calidad de llamada VoIP el valor de $\boldsymbol{\delta}$ máximo en un sentido no debe ser mayor 
a $150 \mathrm{~ms}$, en cuanto al PL este no debe exceder el $1 \%$ (Dialogic Corporation, 2007) y el jitter promedio en un solo sentido debe ser bajo $30 \mathrm{~ms}$ (Hattingh \& Szigeti, 2004). Este procedimiento se repite con los códecs G.711 y G.729 de dos muestras, en los tres subescenarios, los parámetros de configuración de D-ITG se muestran en la TABLA 3.

En la segunda fase de pruebas, para determinar la QoE del servicio de VoIP se elaboró una prueba de opinión sobre la conversación a una muestra de treinta estudiantes de Ingeniería en Electrónica y Telecomunicaciones de la ESPE. La ITU-T Rec. P.800 no menciona un número mínimo de participantes, sin embargo, la ITU-T Rec. P.830 recomienda un mínimo de dos hombres y dos mujeres; además, en la ITU-T Rec. P.910 se aclara que las pruebas de utilidad en terminales o servicios varían de cuatro a cuarenta. Esta fase de pruebas se ejecutó en junio de 2017. La muestra estuvo constituida por un $80 \%$ de hombres y $20 \%$ de mujeres, en un rango de edad entre 22 y 27 años, utilizando la aplicación de VoIP Zoiper en sus smartphones, como se muestra en la Figura 2. La percepción de usuario sobre la calidad de cada llamada se analizó con el método MOS, que para situaciones de conversación se denomina MOSc [Mean Opinion Score Conversational] el cual es el promedio de los valores obtenidos en la escala de calidad ACR entre todos los usuarios, mostrada en la TABLA 4. La metodología implementada consistió en que cada usuario debía mantener un diálogo propuesto de 90s de duración con otro usuario, y al final de la conversación puntuar en la escala ACR según su percepción, este procedimiento se repitió cada vez que se aumentaba progresivamente el número de llamadas simultáneas. Esta metodología se llevó a cabo en los tres subescenarios.

\section{Resultados}

En esta sección se presentan y analizan las métricas de desempeño más importantes para cada escenario propuesto, así como los resultados del método MOSc.

$\eta$ se define como la cantidad de información entregada con éxito por unidad de tiempo en un canal de comunicaciones y se utiliza para el cálculo del throughput normalizado $\eta_{N}$ como medida de eficiencia mediante la ecuación (1), Lara et al., (2016).

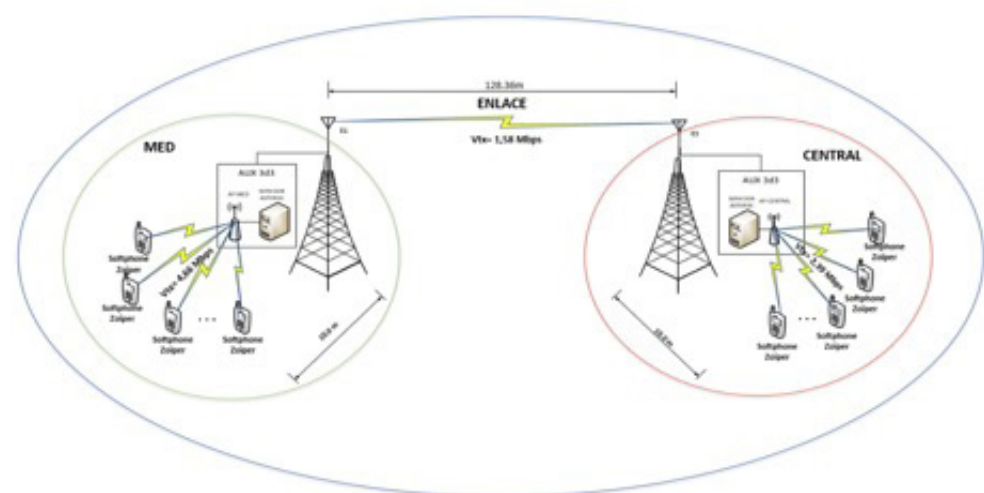

Figure 2. Network topology for QoE tests / Topología de red para pruebas de QoE
Table 3. D-ITG configuration parameters for multi-flow VolP / Parámetros de configuración de D-ITG para VoIP multiflujo

\begin{tabular}{lrr}
\hline Sub-scenario & Códec & Códec \\
& G.711 & G.729 \\
\hline Data type for layer of aplication / & Voice/ & Voice/ \\
Tipo de dato en la capa de aplicación & Voz & Voz \\
Flow / Flujo & Multiflow/ & Multiflow/ \\
& multiflujo & multiflujo \\
Metric / Métrica & one-way- & 15984 \\
& delay & \\
Transport layer protocol / Protoco- & UDP & UDP \\
lo capa transporte & & 90 \\
$\begin{array}{l}\text { Duration (s) / Duración (s) } \\
\text { Bandwidth of 1 flow (kbps)/ }\end{array}$ & 90.1 & 24.0 \\
$\begin{array}{l}\text { Ancho de banda de 1 flujo en (kbps) } \\
\text { Packet rate (p/s) / Tasa de paquete }\end{array}$ & 50.0 & 50.0 \\
(p/s) & & 60 \\
Packet size (bytes) / Tamaño de & & \\
paquete (Bytes) & 200 & \\
\hline
\end{tabular}

In the second testing phase, we made an opinion test regarding the conversation to determine the QoE of the VoIP service. This test was applied to a set of 30 students of Electronics and Telecommunications Engineering of the ESPE. The ITU-T Rec. P.800 does not mention a minimal number of survey respondents; nevertheless, the ITU-T Rec. P.830 suggests a minimal of two men and two women. Besides, the ITU-T Rec. P.910 indicates that the utility tests in terminals or services vary from 4 to 40 . This test phase was executed in June of 2017. The sample was formed by $80 \%$ men and 20\% women with a range of ages between 22 and 27 years old. We used the Zoiper VoIP softphone on their smartphones as per Figure 2 shows. The user perception on the quality of each call was analyzed using the MOS method; for conversational situations, this parameter is called MOSc (conversational MOS), which is the average of the values obtained in the ACR scale between all the users. This information is showed in TABLE 4 .

The implemented methodology consisted of the fact that each user should maintain a dialog of 90 seconds with other user and, at the end of the conversation, they should score in the ACR scale as per his/her own perception. This procedure was repeated each time the number of simultaneous calls was increasing progressively and we carried out this methodology in the three proposed sub-scenarios. 


\section{Results}

We present and analyze the most important performance metrics for each proposed scenario in this section, plus the MOSc method results.

$\eta$ is defined as the amount of information successfully delivered per time unit in a communications channel and it is used for the calculation of the normalized throughput $\eta_{N}$ as an efficiency measurement through equation (1) (Lara et al., 2016).

$$
\eta_{N}=\frac{\eta}{R B R}
$$

(1)

Here, RBR stands for raw bit rate, which is the net transmission rate. In percental terms, the efficiency corresponds to $\eta_{\mathrm{N}}(\%)=\eta_{\mathrm{N}} \times 100$.

For the analysis of $\eta$, we defined three efficiency types: the channel efficiency for any kind of traffic (ל), the efficiency of the VoIP service in the channel $(\psi)$, and the efficiency of the audio codec regarding its $\mathrm{V}_{\mathrm{TX}}$ $(\varepsilon)$.

The real channel capacity on each sub-scenario is determined by the medium value of the injections I3-I7, $\overline{\mathrm{X}}$. This, because these injections present PL values near 0 and their $\zeta$ was calculated regarding a $6 \mathrm{Mbps} \mathrm{RBR}$ for Enlace and Central. On the other hand, the same parameter was calculated for MED as $9 \mathrm{Mbps}$, since this is the value defined by
Table 4. ACR scale / Escala ACR

\begin{tabular}{|c|c|c|}
\hline ACR scale & $\begin{array}{l}\text { Códec } \\
\text { G.711 }\end{array}$ & Códec G.729 \\
\hline 5 & $\begin{array}{l}\text { Excellent / } \\
\text { Excelente }\end{array}$ & $\begin{array}{l}\text { Perfect conversation with exce- } \\
\text { llent quality / Conversación perfecta } \\
\text { con calidad excelente }\end{array}$ \\
\hline 4 & $\begin{array}{l}\text { Good / } \\
\text { Buena }\end{array}$ & $\begin{array}{l}\text { Good quality, although capable } \\
\text { to be improved / Calidad buena, } \\
\text { aunque mejorable }\end{array}$ \\
\hline 3 & $\begin{array}{l}\text { Regular / } \\
\text { Regular }\end{array}$ & Slightly upset / Ligeramente molesta \\
\hline 2 & Poor / Pobre & $\begin{array}{l}\text { Very upset, hard to maintain a } \\
\text { conversation / Muy molesta, dificil } \\
\text { mantener conversación }\end{array}$ \\
\hline 1 & Bad / Mala & $\begin{array}{l}\text { Impossible to maintain a conver- } \\
\text { sation / Imposible mantener conver- } \\
\text { sación }\end{array}$ \\
\hline
\end{tabular}

Donde RBR [Raw Bit Rate] es la tasa neta de transmisión. En porcentaje la eficiencia corresponde a $\eta_{N}(\%)=\eta_{N} \times 100$.

Para el análisis de $\eta$ se definieron tres tipos de eficiencias:

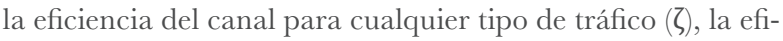
ciencia del servicio de VoIP en el canal $(\psi)$ y la eficiencia del códec de audio $\neg \neg$ respecto de $\mathrm{su}_{\mathrm{TX}}(\varepsilon)$.

Table 5. Results of traffic injection in the channel flooding process to determine the real channel capacity per sub-scenario / Resultados de inyecciones de tráfico en el proceso de inundación del canal para determinar la capacidad real del canal en cada subescenario

\begin{tabular}{|c|c|c|c|c|c|c|}
\hline Subscenario & Parameter & I1 & $\mathrm{I} 2$ & $\mathrm{I} 3$ / I4 / I5 / I6 / I7 & $\overline{\mathbf{x}}(k b p s)$ & $\zeta(\%)$ \\
\hline \multirow[t]{3}{*}{ Enlace } & PL $(\%)$ & 40,39 & 12,49 & $0,57 / 0,1 / 0,11 / 0,3$ & & \\
\hline & $\begin{array}{l}\text { bitrate } \\
\text { (kbps) }\end{array}$ & 1,605 & 1,689 & $\begin{array}{l}1359,942 / 1543,718 / \\
1693,951 / 1421,731 /\end{array}$ & 1588,57 & 26,47 \\
\hline & & & & 1923,55 & & \\
\hline \multirow[t]{2}{*}{ Central } & PL $(\%)$ & 78,87 & 43,25 & $\begin{array}{r}0,89 / 0,00 / 0,03 / 0,43 \\
/ 0,39\end{array}$ & & \\
\hline & $\begin{array}{l}\text { bitrate } \\
\text { (kbps) }\end{array}$ & 376,983 & 1471,743 & $\begin{array}{r}2330,988 / 2426,531 / \\
2444,012 / 2359,45 / \\
2401,28\end{array}$ & 2392,45 & 39,87 \\
\hline \multirow[t]{2}{*}{ MED } & PL $(\%)$ & 36,69 & 17,55 & $\begin{array}{r}0,00 / 0,84 / 2,21 / 6,46 \\
/ 0,01\end{array}$ & & \\
\hline & $\begin{array}{l}\text { bitrate } \\
\text { (kbps) }\end{array}$ & 4579,837 & 4080,123 & $\begin{array}{r}4492,126 / 4797,305 / \\
4596,799 / 4295,25 / \\
5150,551\end{array}$ & 4666,40 & 51,84 \\
\hline
\end{tabular}


Table 6. $\psi$ of the VolP service regarding $\bar{x}$ on each sub-scenario / $\psi$ del servicio de VolP respecto a $\overline{\mathrm{x}}$ de cada subescenario

\begin{tabular}{lrrrr}
\hline Subscenario & Codec & $\eta(\mathrm{kbps})$ & $(\mathrm{kbps})$ & $\psi(\%)$ \\
\hline Enlace & G.711 & 325,99 & 1588,57 & 20,52 \\
& G.729 & 60,69 & & 3,82 \\
Central & G.711 & 327,44 & 2392,45 & 13,68 \\
& G.729 & 61,55 & & 2,57 \\
MED & G.711 & 1318,22 & 4666,40 & 28,24 \\
& G.729 & 305,50 & & 6,54 \\
\hline
\end{tabular}

La capacidad real del canal en cada subescenario está determinada por el valor medio $\overline{\mathrm{X}}$ de las inyecciones (I3-I7), debido a que presentan valores de PL cercanos a 0 , su $\zeta$ se calculó respecto a un RBR de 6 Mbps para Enlace y Central, mientras que 9 Mbps para MED, ya que es el RBR definido por la sensibilidad del equipo al momento de pruebas, de acuerdo con el estándar IEEE $802.11 \mathrm{~g}$. La TABLA 5 muestra los resultados de esta primera instancia de pruebas.

La ocupación de canal por parte del servicio de VoIP se describe en la Tabla 6, donde se muestra que en todos los subescenarios el códec G.711 alcanza valores de $\psi$ superiores a G.729, adicionalmente se observa que en MED se presenta el valor más alto (28\% aproximadamente). Cabe aclarar que

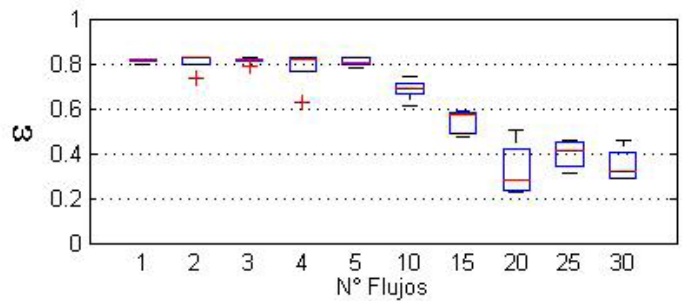

a)

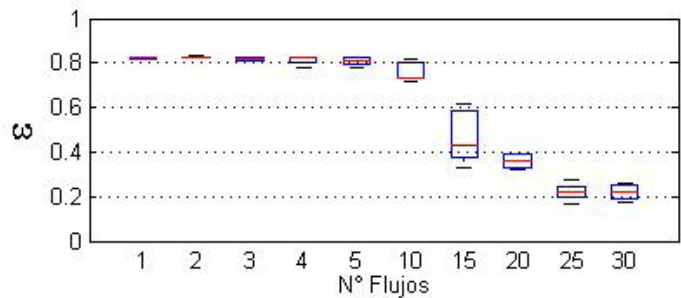

c)

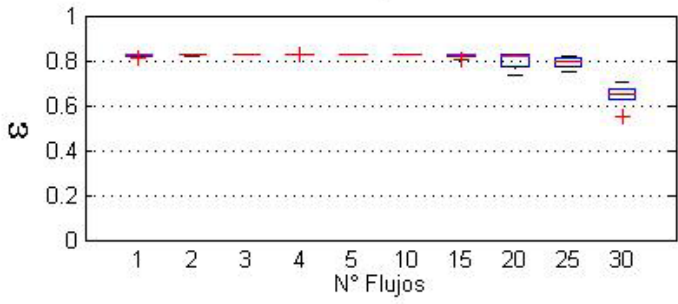

e) the sensitiveness of the equipment according with the IEEE $802.1 \mathrm{~g}$ standard. TABLE 5 presents the results of this first testing stage.

The channel occupation per VoIP service is described in TABLE 6 , where the reader can see that, in all the sub-scenarios, the G.711 codec reaches $\psi$ values superior to G.729. Additionally, the highest value of this parameter was in MED (28\%). It is important to focus that this value was calculated considering the maximum number of simultaneous VoIP flows under $1 \%$ of PL. For this reason, the RBR equals to $\overline{\mathrm{X}}$ on each sub-scenario.

The RBR for the case of VoIP multi-flow packets was treated as per equation (2) (Ahson \& Ilyas, 2009).

$$
R B R=n \times A B_{\text {codec }}
$$

where $\mathrm{n}$ is the number of simultaneous injected flows and $A B_{\text {codec }}$ is the bandwidth of a single flow for the codecs G.711 and G.729.

Figure 3 presents that the G.711 codec reaches the higher $\varepsilon$, by obtaining a value of approximately $80 \%$. Likewise, it is possible to see that when 1 to 5 simultaneous flows are pres-

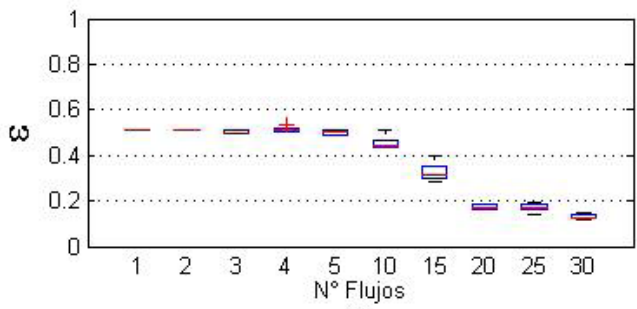

b)

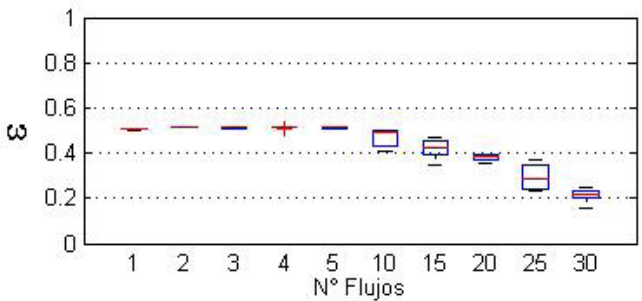

d)

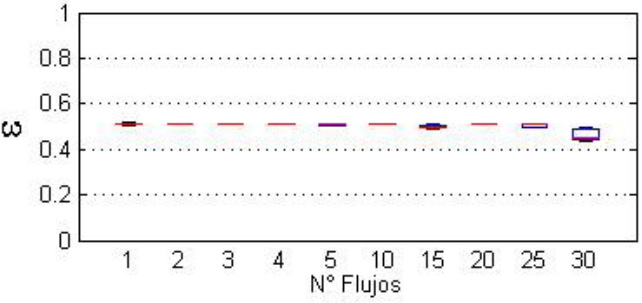

Figure 3. $\varepsilon$ in function of the injected number of flows in the three sub-scenarios: Enlace, Central, and MED respectively, a)-c)-e) tests with the G.711 codec and b)-d)-f) tests with the G.729 codec / $\varepsilon$ en función del número de flujos inyectados en los tres subescenarios: Enlace, Central y MED respectivamente, a-c-e) pruebas con el códec G.711 y b-d-f) pruebas con el códec G.729 
ent, stability is guaranteed in the first two sub-scenarios, since the variance on their measurements is not relevant. Nonetheless, in MED, the $\varepsilon$ value is constant up to 25 flows. On the other hand, G.729 presents a similar behavior in the first two sub-scenarios where $\varepsilon$ reaches a top of $55 \%$ in the first 5 flows, reducing this value when the maximum simultaneous flows grow. Contrarywise, in MED for G.729, this value is constant until 25 flows are surpassed.

Figure 4 presents the PL results of the three sub-scenarios, where the reader is able to see that in Enlace, the PL is lower than $1 \%$ up to 5 simultaneous flows; after that, the growing is almost linear up to 20 simultaneous flows, reaching a maximum PL of $72 \%$ in 30 flows for the G.729 codec. On the other hand, G.711 has 20\% less packet loss relative to G.729. It is important to mention that in this sub-scenario, the value of $10 \%$ in $\mathrm{PL}$ is reached before the 10 flows with both codecs; from 20 flows, a slightly decrease in the PL was observed. This behavior is discussed in Section 5. In the Central location, the codec with larger \% of PL is G.711 with a maximum of $70 \%$ for 25 flows. The G.729 codec presents a value of $56 \%$ when 30 flows are reached.

The PL results within MED are constant and its value is ideal up to 20 flows with G.711; with G.729, this ideality (i.e., $\mathrm{PL}<1 \%$ ) is maintained up to 25 flows

In Figure 5, we show the obtained $\boldsymbol{\delta}$ values as follow: in Enlace, a maximum of 2,200 ms was reached with the G.711 codec in 20 flows; very above the values described by the ITU-T Rec. G.114 (i.e., 150 ms). Additionally, an unstable behavior is observed relative to the number of flows. G.729 el valor de $\psi$ se calculó respecto del número máximo de flujos simultáneos de VoIP bajo el 1\% de PL. En este caso el RBR equivale a $\overline{\mathrm{X}}$ en cada subescenario.

El RBR para el caso de paquetes de VoIP multiflujo fue tratado mediante la ecuación (2) (Ahson \& Ilyas, 2009).

$$
R B R=n \times A B_{\text {codec }}
$$

Donde $\mathrm{n}$ es el número de flujos simultáneos inyectados y $A B_{\text {codec }}$ corresponde al ancho de banda de un solo flujo para los códecs G.711 o G.729.

En la Figura 3 se observa que el códec G.711 alcanza la mayor $\varepsilon$ obteniendo un valor de $80 \%$ aproximadamente. Además, se aprecia que de uno a cinco flujos simultáneos se presenta una mayor estabilidad en los dos primeros subescenarios ya que la varianza de sus medidas es insignificante. Sin embargo, en MED el valor de $\varepsilon$ se mantiene constante hasta los veinticinco flujos. Por otro lado, G.729 muestra un comportamiento similar en los dos primeros subescenarios, en donde $\varepsilon$ alcanza un máximo de $55 \%$ en los primeros cinco flujos, reduciendo este valor conforme se aumenta el número de flujos simultáneos, con excepción de MED, donde este valor se mantiene constante hasta sobrepasar los veinticinco flujos.

En la Figura 4 se observan los resultados de PL de los tres subescenarios, donde se muestra que en Enlace el PL es inferior al $1 \%$ hasta cinco flujos simultáneos y tiene un posterior crecimiento casi lineal, conforme aumenta el número de flujos hasta los veinte simultáneos, y alcanza un valor máximo aproximado de $72 \%$ en treinta flujos para el códec G.729, mientras que G.711 tiene un 20\% menos de PL respecto al anterior. Cabe resaltar que en este subescenario se alcanza un $10 \%$ de PL antes de los diez flujos con ambos códecs y a partir de los veinte flujos simultáneos se produce un leve descenso de PL, este comportamiento se discute en la sección cinco.

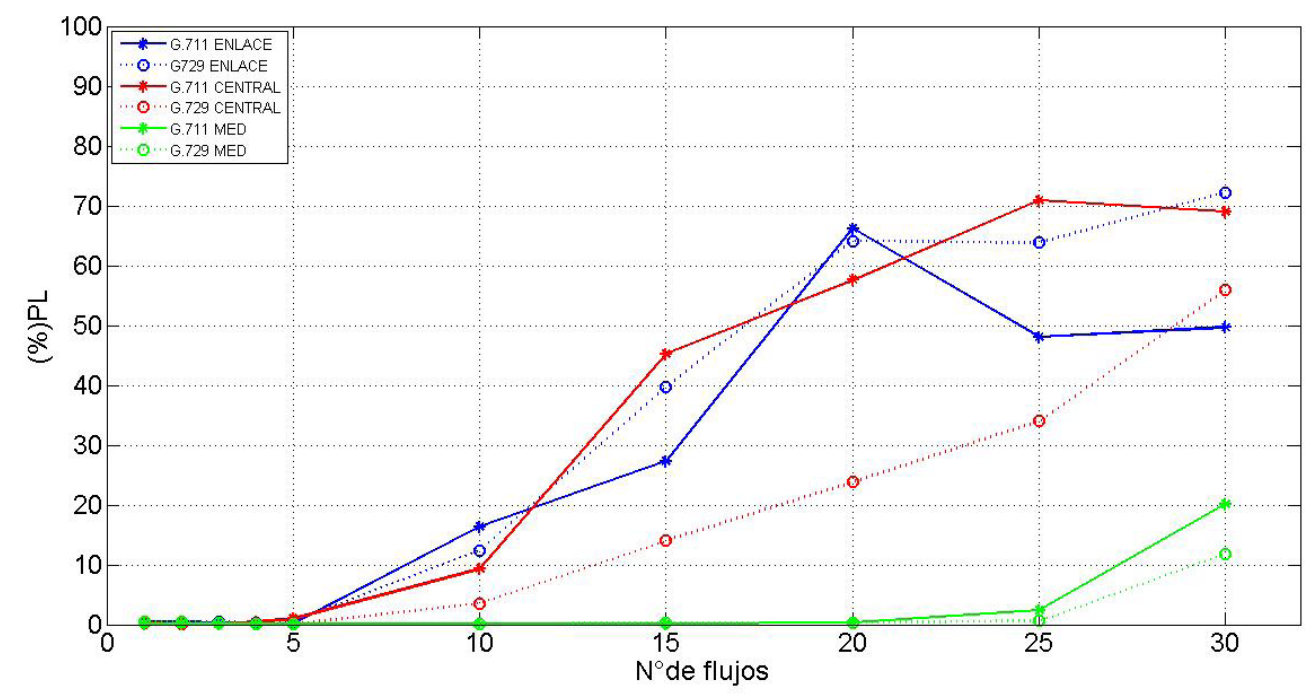

Figure 4. PL for the G.711 and G.729 codecs in the three sub-scenarios: Enlace, Central, and MED regarding the number of flows / PL para los códecs G.711 y G.729 en los tres sub escenarios Enlace, Central y MED respecto del número de flujos 


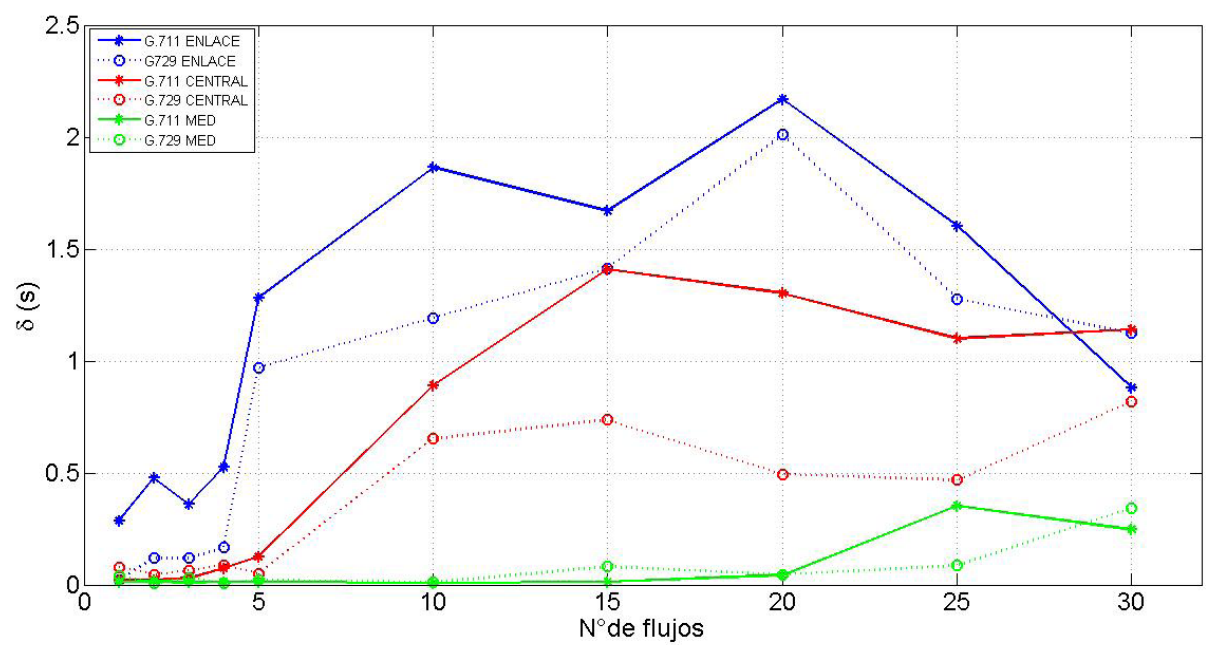

Figure 5. $\delta$ of the G.711 and G.729 codecs in the three sub-scenarios: Enlace, Central, and MED as per the number of flows / $\delta$ de códecs G.711 y G.729 en los tres subescenarios Enlace, Central y MED según el número de flujos

En el emplazamiento Central, el códec que tiene el mayor porcentaje de PL es el G.711, con un máximo de 70\% para veinticinco flujos, y en el caso del G.729 presenta un valor de $56 \%$ a los treinta flujos. Por otro lado, los resultados de PL dentro de MED se mantienen constantes y su valor es ideal hasta que supera los veinte flujos con G.711 y respecto del G.729 se soportan hasta veinticinco flujos bajo el 1\% de PL.

En la Figura 5 se muestran los valores obtenidos de $\boldsymbol{\delta}$; en Enlace se alcanza un máximo de 2,200 ms con el códec G.711 en veinte flujos, muy por encima del valor descrito por la ITU-T Rec. G.114, de 150 ms, además posee un comportamiento inestable respecto del número de flujos. G.729 presenta un $\boldsymbol{\delta}$ máximo de $2000 \mathrm{~ms}$ aproximadamente, un valor aún por encima del ideal. El subescenario Central permite hasta cinco flujos con $\boldsymbol{\delta}$ inferiores a $150 \mathrm{~ms}$ y una posterior tendencia exponencial creciente hasta los quince flujos para ambos códecs, a partir de esto se presenta una leve mejoría presents a maximum $\boldsymbol{\delta}$ of 2,000 ms approximately — a value still very high from the ideal- - The Central sub-scenario allows up to 5 flows with $\boldsymbol{\delta}$ lower than $150 \mathrm{~ms}$ and after, it presents a growing exponential trend up to 15 flows for both codecs. After that, a slightly improvement is reached up to 30 simultaneous flows. MED is the location where best results were achieved, with a relatively constant behavior and lower than 150 ms for both G.711 and G.729 up to reach 20 flows.

FIGURE 6 presents the obtained results in the delay variation (i.e., jitter) in the proposed scenarios for both assessed codecs. Within Enlace, the jitter presents large variations by obtaining a maximum value of $99 \mathrm{~ms}$ for G.711 and $80 \mathrm{~ms}$ for G.729 in 20 simultaneous flows. Whilst in Central, the values reach up to $90 \mathrm{~ms}$ for G.711 and only half of the last value (45 ms) for G.729. Finally, MED presented a slight vari-

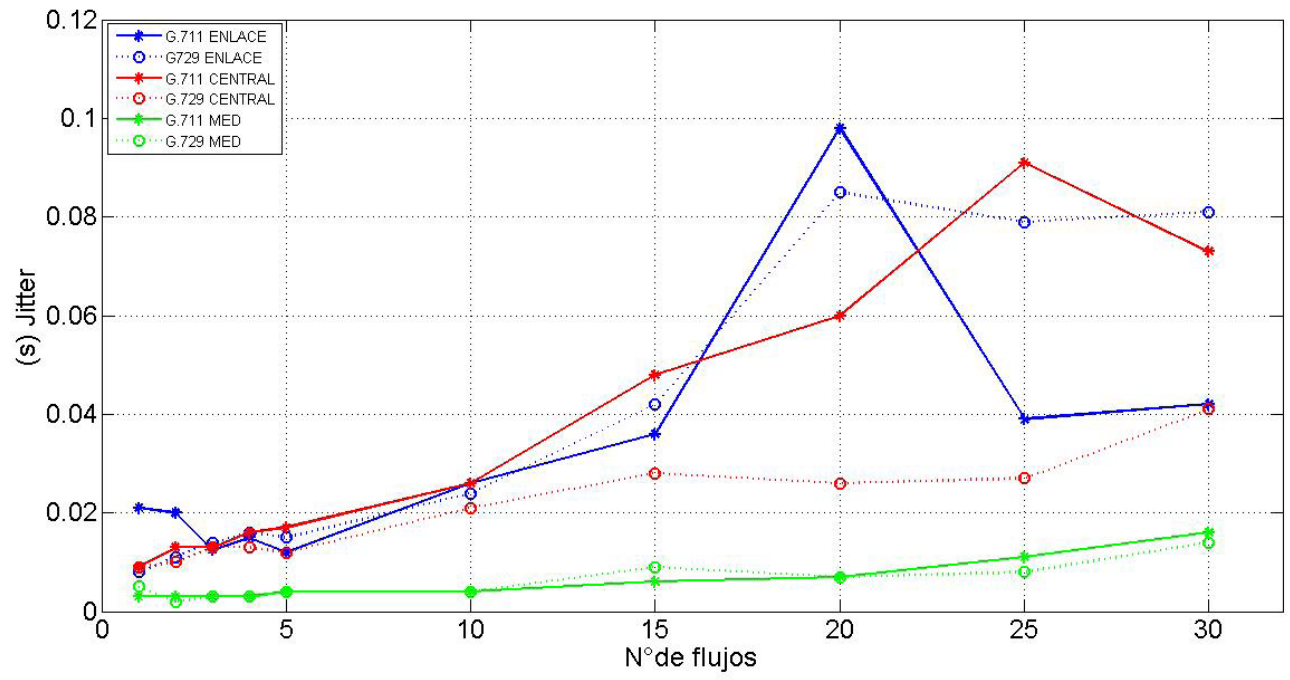

Figure 6. Jitter in function of the number of flows with the G.711 and G.729 codecs in the three sub-scenarios / Jitter en función del número de flujos con los códecs G.711 y G.729 en los tres subescenarios 


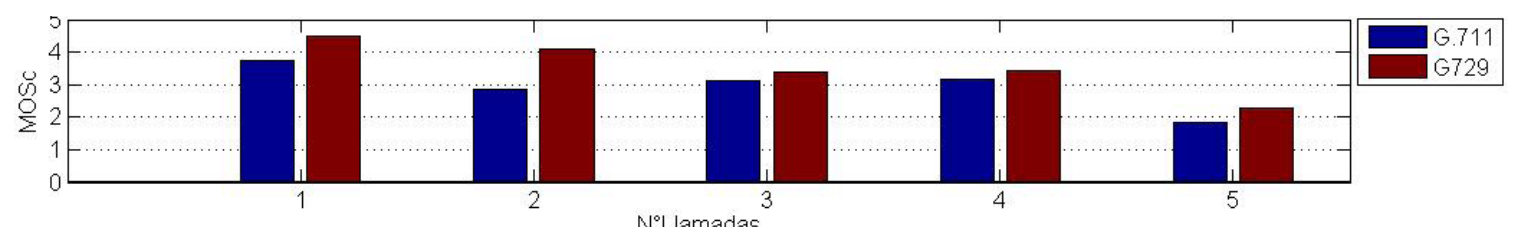

a)

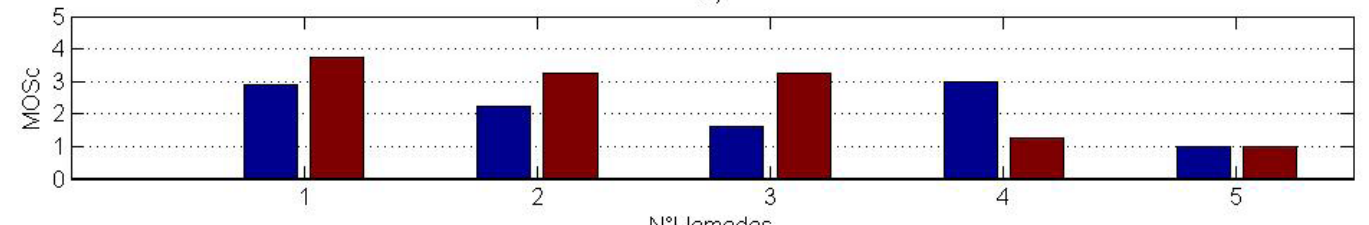

$N^{\circ}$ Llamadas

b)

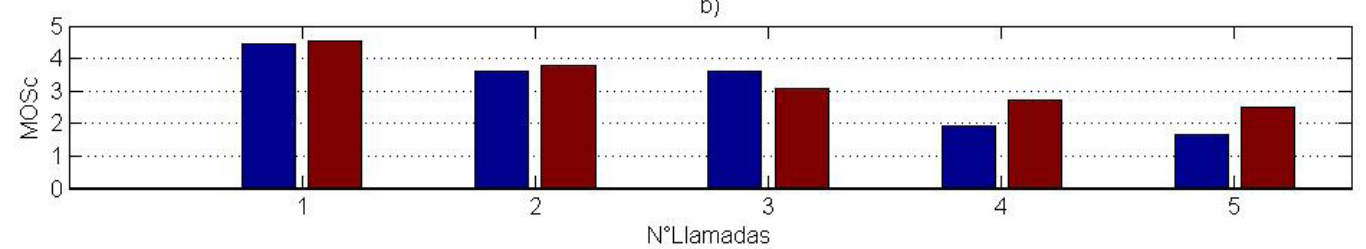

c)

Figure 7. MOSc vs number of calls for the three sub-scenarios: a) Enlace, b) Central, and c) MED, and two audio codecs / MOSc vs número de llamadas para los tres subescenarios: a) Enlace, b) Central, y c) MED, y dos códecs de audio

ation of the jitter values for both codecs up to reaching 15 ms. The obtained jitter values in all the sub-scenarios are in the proposed range in the ITU-T Rec. P.800.

FiguRE 7A) corresponds to the Enlace sub-scenario, which presents a regular score with up to 4 simultaneous calls and only with 5 calls the quality drops to poor. Instead, FigURE 7в) evidences that Central has the lowest scores with a low-predictable component as per the number of simultaneous calls grow. Lastly, FIGURE 7c) corresponds to the MED location where the quality of the first call was marked as good, but as per the number of simultaneous calls grow, the quality tends to decrease too. Likewise, it is possible to confirm that the G.729 codec has a better score regarding the G.711, but their behavior was similar in the rest of sub-scenarios.

\section{Discussion and conclusions}

The evaluation of the maximum capacity of simultaneous sessions was performed by using the optimum values of the metrics associated to the QoS as per the ITU-T recommendations for VoIP. In the MED sub-scenario — where the less number of interfering networks and devices are present-, G.729 reached up to 25 simultaneous sessions, whilst G.711 made 20. In Central, up to 5 simultaneous sessions were reached with both audio codecs, whilst Enlace only supported 4 simultaneous sessions with G.729. The G.711 codec showed a $\boldsymbol{\delta}$ value higher than the optimum one. On the other hand, the total channel occupation of the G.711 codec was approximately 5 times larger than the one obtained by hasta alcanzar los treinta flujos simultáneos. MED es el que mejores resultados presenta, con un comportamiento relativamente constante inferior a $150 \mathrm{~ms}$ tanto en G.711 como en el G.729 hasta alcanzar los veinte flujos.

En la Figura 6 se presentan los resultados obtenidos en la variación del $\boldsymbol{\delta}$ o jitter en los escenarios propuestos, tanto para el códec G.711, como para G.729. En Enlace, el jitter presenta grandes variaciones, se obtiene un máximo de $99 \mathrm{~ms}$ con G.711 y 80 ms con el G.729 en veinte flujos simultáneos, mientras que en el subescenario Central se tiene un crecimiento hasta alcanzar 90 ms con el G.711, diferente a G.729 que presenta la mitad de este valor. Finalmente, en MED los valores para ambos códecs fluctúan ligeramente hasta alcanzar los 15 ms. Los valores de jitter obtenidos se encuentran dentro del rango adecuado propuesto por la ITU-T Rec. P.800 en los tres subescenarios.

La Figura 7a) corresponde al subescenario Enlace que presenta una calificación regular hasta con cuatro llamadas simultáneas y sólo en cinco llamadas decrece a calidad pobre. Por otro lado, la Figura 7B) evidencia que Central tiene las más bajas calificaciones, con un comportamiento poco predecible según aumenta el número de llamadas simultáneas. Finalmente, la Figura 7c) corresponde a MED donde la calidad de la primera llamada se calificó como buena, pero conforme aumenta el número de llamadas simultáneas, la calidad tiende a decrecer, de igual manera se aprecia que el códec G.729 tiene una mejor valoración respecto al G.711, de comportamiento similar al resto de subescenarios.

\section{Discusión y conclusiones}

La evaluación de la capacidad máxima de sesiones simultáneas se realiza considerando los valores óptimos de las métricas asociadas a QoS según las recomendaciones de la ITU-T 
para VoIP. En el subescenario MED, donde se manifiestan la menor cantidad de redes y dispositivos interferentes, G.729 alcanzó hasta veinticinco sesiones simultáneas, mientras que con el códec G.711 se lograron veinte. En Central se alcanzó hasta cinco sesiones concurrentes con ambos códecs de voz, mientras que Enlace soporta tan solo hasta cuatro sesiones simultáneas con G.729, a diferencia de G.711 que muestra un valor de $\boldsymbol{\delta}$ mayor al óptimo. Por otro lado, la ocupación de canal por parte del códec G.711 es aproximadamente cinco veces superior que la obtenida por el G.729, lo cual se repite en todos los subescenarios, mientras que únicamente en MED, la $\zeta$ presenta un valor acorde a la eficiencia del estándar IEEE $802.11 \mathrm{~g}$ obteniendo un 52\% aproximadamente. De igual forma, el códec que mejor eficiencia presenta en cuanto a VTX, es el G.711, alcanza una $\varepsilon=80 \%$, mientras que G.729 tan solo logra un $\varepsilon=55 \%$. Además, se resalta que en MED se obtuvo una mayor estabilidad para ambos códecs, manteniendo una $\varepsilon$ constante hasta alcanzar los flujos veinticinco concurrentes. No obstante, en el resto de subescenarios se presenta una estabilidad uniforme hasta cinco flujos simultáneos. Del mismo modo, los resultados de la evaluación de QoE a través de pruebas con usuarios reales señalan que, pese a seguir una tendencia similar, G.729 presenta una mejor valoración de MOSc respecto a G.711.

Igualmente, como se mencionó en la TABLA 3, el códec G.729 utiliza menor ancho de banda que G.711, lo que resulta en una mayor capacidad de flujos simultáneos de VoIP. A diferencia de las características de VoIP sobre redes cableadas, en redes inalámbricas el número máximo de llamadas simultáneas no equivale a dividir el ancho de banda total entre el ancho de banda del códec, pues este factor se ve limitado debido a la capacidad del buffer del AP y la contienda por el medio. Esta última viene determinada por el protocolo MAC del estándar IEEE $802.1 \mathrm{lg}$, lo cual influye en el enlace descendente, como mencionan Keegan y Davis (2006) y concluyen Oliveira y Siqueira (2006). Además, el PL y $\boldsymbol{\delta}$ impiden que se puedan soportar más llamadas luego de que se supera el límite de capacidad para cada subescenario, por lo que son estos los parámetros de mayor influencia en la degradación de QoS. Cabe mencionar que, a pesar de que el estándar IEEE $802.1 \mathrm{lg}$ no soporta el aprovisionamiento de QoS, se pudo asegurar el número de sesiones simultáneas mencionadas en cada subescenario bajo los umbrales óptimos establecidos por la ITU-T para transmisión de voz en tiempo real.

En el trabajo de Villacís et al., (2013) se propone evaluar el comportamiento de versiones más actuales del SO Voyage-One para determinar el comportamiento de \% de CPU y de memoria RAM. En este estudio, utilizando Voyage-One 0.8.5 se determinó que el \% de CPU no sobrepasa el $11 \%$ y un 7\% de RAM hasta la capacidad límite de llamadas simultáneas que permitió la red, por lo cual concluimos que el costo computacional no es influyente en la determinación de la capacidad máxima de llamadas en un escenario real. En contraste con el trabajo mencionado, donde obtuvo que, para el códec G.711 y bajo el estándar IEEE 802.11g, el \%
G.729, a behavior observed in all the sub-scenarios, whilst only in MED the $\zeta$ presents a value in accordance with the IEEE $802.11 \mathrm{~g}$, obtaining a $52 \%$ approximately.

Likewise, the codec that presented the most favorable efficiency regarding the VTX was G.711: it reached an $\varepsilon$ value of $80 \%$, whilst G.729 made only up to $55 \%$. Besides, we obtained a larger stability for both codecs in the MED location by maintaining a constant $\varepsilon$ until reaching 25 concurrent flows. Nonetheless, in the remaining sub-scenarios we obtained a uniform stability up to 5 simultaneous flows. Likewise, the QoE evaluation results through tests with real users indicate that, regardless of following a similar trend, G.729 presented a better MOSc score than G.711.

Similarly, as we mentioned in Table 3, the G.729 codec uses lower bandwidth than the G.711 one, which results in a larger capacity to handle simultaneous VoIP flows. Unlike the VoIP features in wired networks, in wireless environments the maximum number of simultaneous calls does not equals to divide the total bandwidth between the codec bandwidth, since this latest factor is limited due to the AP buffering capacity and the dispute for the medium. This latter is determined by the MAC protocol of the IEEE $802.11 \mathrm{~g}$ standard, which influences in the downlink as per Keegan \& Davis (2006) mention and Oliveira \& Siqueira (2006) conclude. Additionally, the PL and the $\boldsymbol{\delta}$ values prevent the handling of more calls after the capacity limit is surpassed on each sub-scenario; hence, these are the most influential parameters in the QoS degradation.

It is important to mention that, although the IEEE 802.11g standard does not support the QoS provisioning, we were able to ensure the number of simultaneous sessions mentioned on each sub-scenario under the optimum values established by the ITU-T for voice transmission in real-time.

The work presented by Villacís et al., (2013), the authors propose to assess the behavior of more up to date versions of the Voyage-One operating system to determine the behavior of CPU percentage and RAM memory. The Voyage-One 0.8 .5 version was employed by them and it was determined that the CPU \% does not pass the $11 \%$ in usage and the RAM was used up to $7 \%$ when the top capacity of simultaneous calls the network allows was present. Consequently, we can conclude that the computational cost is not influential in the determination of the maximum calls capacity in a real scenario. Unlike the mentioned work, where the authors obtained that for G.711 and under the IEEE 802.11 g standard, the CPU percentage reached its maximum capacity with 46 
simultaneous calls, using $8.5 \%$ of the total RAM in a laboratory scenario. This result is opposite to the ones we have found in this document.

Figures 4, 5, and $\mathbf{6}$-corresponding to PL, $\boldsymbol{\delta}$ and jitter- show an irregular behavior from 20 simultaneous flows, presenting an important improvement for the Enlace sub-scenario. The network variability is due to the high traffic in the networks of the campus, since the adjacent AP are automatically configured to use several wireless channels specifically channel 6, assigned to Enlace- For this reason, an overlapping in the channels was present, which provokes higher interference. Furthermore, the climatic instability also influenced somehow in this sub-scenario. Alternatively, the physical features of the environment and its propagation way vary as per the location of the antenna and the height of the receiver, among others. Finally, in the Wi-Fi link, the maximum power is legally limited; consequently, the maximum distance reached under optimum free space conditions depend on the receiver sensitivity.

Our research group is interested in continuing this research line, for that reason we propose several future works such as the performance evaluation with standards working in the $5 \mathrm{GHz}$ frequency such as IEEE 802.11n and IEEE 802.11ac. This, in order to avoid the channel overlapping. Besides, we propose to implement the system in a rural environment within a long-distance link, due to the relatively low interference it can present. Another idea is to use the IEEE 802.11e standard, which provides QoS support to real-time applications such as voice and video. Lastly, it would be interesting to assess the performance of the Alix card with an operating system with different features than Voyage Linux, i.e., by using a PBX software different than Asterisk, which allows the use of last-generation codecs such as SILK and OPUS, usually employed for social applications with large data demand.

\section{Acknowledgement}

The authors of this research article want to express their gratitude to the Universidad de las Fuerzas Armadas [ESPE] for the economic support in the development of this work through the 2011-PIT-WiLD and 2016-EXT038 projects. SeT de CPU alcanzó su capacidad máxima con 46 llamadas simultáneas y un 8.5\% de RAM en un escenario de laboratorio con simulaciones, lo cual se contrapone a lo determinado en nuestro trabajo.

Las Figuras 4, 5 y $\mathbf{6}$, correspondientes a PL, $\boldsymbol{\delta}$ y jitter muestran un comportamiento irregular a partir de los veinte flujos simultáneos, presentando una mejoría notable para el subescenario Enlace. La variabilidad de la red se debe, entre otras cosas, al elevado tráfico que cursa por las redes inalámbricas del campus universitario, dado que los AP adyacentes en el campus se configuraban automáticamente en los distintos canales inalámbricos, específicamente en el canal 6, el cual fue asignado para Enlace, por lo que existía sobrelapamiento y provocaba una mayor interferencia. Además, la inestabilidad climática influyó en cierta medida sobre este subescenario. Por otra parte, las características físicas del entorno y su forma de propagación varían según la ubicación de la antena y la altura del receptor, entre otros. Finalmente, en el enlace Wi-Fi la potencia legal máxima es limitada, por lo tanto, la distancia máxima que se alcanza bajo condiciones óptimas de espacio libre depende de la sensibilidad del receptor.

Finalmente, nuestro grupo está interesado en continuar esta línea de investigación, por ello se proponen varios trabajos futuros, como la evaluación del rendimiento con estándares que trabajan en la frecuencia de $5 \mathrm{GHz}$ como el IEEE 802.11n e IEEE 802.1 lac, con el fin de evitar el sobrelapamiento de los canales. También se propone implementar el sistema en un ambiente rural con un enlace de larga distancia, dada la poca interferencia que se presenta. Otra idea es utilizar el estándar IEEE 802.11e, que proporciona soporte de QoS a aplicaciones de tiempo real tales como voz y video. Por último, sería interesante evaluar el desempeño de la tarjeta Alix con un sistema operativo con características diferentes a Voyage Linux, usando un software de PBX distinto de Asterisk, que permite el uso de códecs de última generación como SILK y OPUS, que son utilizados por aplicaciones sociales de alta demanda.

\section{Agradecimiento}

Los autores desean expresar su agradecimiento a la Universidad de las Fuerzas Armadas [ESPE] por el apoyo económico en el desarrollo de este trabajo a través de los proyectos 2011-PIT-WiLD y 2016-EXT-038. ST 


\section{References / Referencias}

Agredo, G. \& Gaviria, J. (2006). Evaluación experimental de la capacidad de IEEE 802.11 b para soporte de VoIP. Sistemas \& Telemática, 4(8), 125-151. Retrieved from: http://www.redalyc.org/pdf/4115/411534375007.pdf

Ahson, S. \& Ilyas, M. (2009). VolP Handbook: Applications, technologies, reliability, and security. Boca Ratón, FL: CRC.

Evans, A. \& Britain, K. (1989). Antennas: Selection and installation. Boston, MA: Radio Shack.

Avallone, S., Guadagno, S., Emma, D., \& Ventre, G. (Sept. 2004). D-ITG distributed Internet traffic generator. In: Proceedings of the First International Conference on the Quantitative Evaluation of Systems QEST 2004 (pp. 316-317). IEEE.

Cano, M.D. \& Cerdan, F. (2012). Subjective QoE analysis of VoIP applications in a wireless campus environment. Telecommunication Systems, 49(1), 5-15.

Canonical Ltd. (2016). Ubuntu 15.04. Retrieved from: http://releases.ubuntu.com/15.04/

Coleman, D. D., \& Westcott, D. A. (2009). CWNA: Certified wireless network administrator official study guide. Sybex. Indianapolis, IN: Wiley

Dialogic Corporation. (2007). Overcoming barriers to high-quality voice over IP Deployments [white paper] Retrieved from: http://www.sumopartner.com/Resources/images/17480.pdf

Dini, P., Font-Bach, O., \& Mangues-Bafalluy, J. (2008). Experimental analysis of VolP calls quality support in IEEE 802.11 DCF. In Proceedings of the 6th International Symposium on Communication Systems, Networks and Digital Signal Processing (pp. 443-447). IEEE.

Farproc. (2017). Wifi analyzer [Android App]. Retrieved from: http://www.wifianalyzer.info/

Frost \& Sullivan (2017, January 3). Growth opportunities in the VolP access and SIP trunking services market [white paper]. Retrieved from: https://www.frost.com/c/10107/sublib/display-report.do?id=KOFC-01-00-00-00

Geier, J. (2010). Designing and deploying 802.11n wireless networks. Indianapolis, IN: Cisco.

Hattingh, C., \& Szigeti, T. (2004). End-to-end QoS network design: Quality of service in LANs. WANs and VPNs. Indianapolis, IN: Cisco

IBM Knowledge Center. (2011). SPSS data collection 6.0.1: Call duration. Retrieved from: https://www.ibm.com/support/ knowledgecenter/en/SSLVQG 6.0.1/com.spss.ddl/mrint autodialer callanalysis callduration.htm

ITU-T Rec. G.114: One-way transmission time. (2003). Geneva, Switzerland: ITU.

ITU-T Rec. P.800: Methods for subjective determination of transmission quality. (1996), Geneva, Switzerland: ITU.

ITU-T Rec. P.830: Subjective performance assessment of telephone-band and wideband digital codecs. (1996). Geneva, Switzerland: ITU

ITU-T Rec. P.910: Subjective video quality assessment methods for multimedia applications. (2008). International Geneva, Switzerland: ITU

Keegan, B. \& Davis, M. (2006). An experimental analysis of the call capacity of IEEE 802.11b wireless local area networks for VolP telephony. In Irish Signals and Systems Conference (pp. 283-287). IET.

Kolahi S.S., Shah M.A., \& Joseph J. (2012). Performance of VoIP on IPv4 and IPv6to4 tunnel using Windows Vista and Windows 7. In: F. Gaol (Ed.), Lecture Notes in Electrical Engineering, 157: Recent progress in data engineering and internet technology (pp. 477-483). Berlin-Heidelberg, Germany: Springer.

Lara, R., Fernández, C., \& Morales, C. (2016). Análisis del desempeño en un enlace descendente de redes basadas en los estándares IEEE 802.11 b, IEEE 802.11n y WDS. RECI, Revista Iberoamericana de las Ciencias Computacionales e Informática, 5(10). Retrieved from: http://reci.org.mx/index.php/reci/article/view/42

Mills, D. L. (1991). Internet time synchronization: The network time protocol. IEEE Transactions on Communications, 39(10), 1482-1493.

Oliveira, C. \& Siqueira, M. (2006). Simultaneous VolP calls capacity over an 802.11 Ad Hoc Network. In: International Conference on Wireless Networks (pp. 470-476). Berlin, Heidelberg: Germany: Springer-ICST.

PC Engines (2013). ALIX 3d3 Product file. Retrieved from: http://www.pcengines.ch/alix3d3.htm

QPCOM. (2011). QP-2424G high-performance reflector grid Wi-Fi antenna. Retrieved from: http://qpcom.com.co/Portals/116/ QPA024G24 Spec.pdf

Ramírez, R. (2013). Implantación de un sistema VolP basado en software libre con Asterisk [Master Thesis]. Universitat Oberta de Catalunya: Barcelona, España.

Ubiquiti Networks (2013). Ubiquiti super range 2. Retrieved from: https://dl.ubnt.com/sr2 datasheet.pdf

Vesga-Ferreira J.C., Granados G., \& Vesga-Barrera J.A. (2016). Evaluation of the performance of a network LAN over powerline communications for the transmission of VolP. Iteckne, 13(1), 83-95.

Villacis, D., Acosta, F., \& Lara, R. (2013). Performance analysis of VolP services over WiFi-based systems. In: IEEE Colombian Conference on Communications and Computing (COLCOM), 2013. Retrieved from: http://ieeexplore.ieee.org/abstract/ document/6564813/

Voyage Design and Consultants (2013). About Voyage Linux. Retrieved from: http://linux.voyage.hk

Winstron Neweb Corp. (2011). Winstron CM9-GP. Retrieved from: http://www.roc-noc.com/pdf/wnc/CM9 Data Sheet.pdf

Zoiper. (2017). Softphone Zoiper 3. Retrieved from: https://www.zoiper.com/ 


\section{CURRICULUM VITAE}

Marcelo David Núñez Cuadrado Candidate to Engineer in Electronics and Telecommunications at the Universidad de las Fuerzas Armadas - ESPE (Sangolquí, Ecuador). En 2016 he joined the Intelligent Systems research group (WICOM) as research assistant. His main areas of interest in research are wireless systems and Voice over IP (VoIP) / Egresado de la carrera de Ingeniería en Electrónica y Telecomunicaciones de la Universidad de las Fuerzas Armadas - ESPE (Sangolquí, Ecuador). En 2016 se unió al grupo de investigación de Sistemas Inteligentes (WICOM) como ayudante de investigación. Sus principales áreas de interés en investigación son los sistemas inalámbricos y la voz sobre IP (VolP).

Carlos Andres Játiva Huilcapi Candidate to Engineer in Electronics and Telecommunications at the Universidad de las Fuerzas Armadas - ESPE (Sangolquí, Ecuador). En 2016 he joined the Intelligent Systems research group (WICOM) as research assistant. He completed the CCNA courses and he is candidate to CISCO certification. His main areas of interests in research are wireless communications and data networks / Egresado de la carrera de Ingeniería Electrónica y Telecomunicaciones de la Universidad de las Fuerzas Armadas ESPE (Sangolquí, Ecuador). En 2016 se unió al grupo de investigación de Sistemas Inteligentes (WICOM) como ayudante de investigación. Finalizó los cursos de CCNA y está próximo a obtener la certificación CISCO. Sus principales áreas de intereses en investigación son las comunicaciones inalámbricas y las redes de datos.

Román Alcides Lara Cueva, Ph.D Engineer in Electronics and Telecommunications from the Escuela Nacional Politécnica (Quito-Ecuador, 2001); Master in Wireless Systems and Related Technologies from the Politecnico di Torino (Italy, 2005); Master and PhD., in Telecommunication Networks for Developing Countries from the Universidad Rey Juan Carlos (Madrid-España, 2010/2015). He joined the Department of Electrical Engineering of the Universidad de las Fuerzas Armadas - ESPE (Sangolquí, Ecuador) in 2002, where he is full professor since 2005. He has participated in more than ten research projects developed with public funds (five of them as main researcher). His main areas of research interests are: digital signal processing, smart cities, wireless systems and automatic learning theory / Ingeniero en Electrónica y Telecomunicaciones de la Escuela Politécnica Nacional (Quito-Ecuador, 2001; Máster en Sistemas Inalámbricos y Tecnologías Relacionadas del Politecnico di Torino (Italia, 2005); Máster y Doctor en Redes de Telecomunicación para Países en Desarrollo de Universidad Rey Juan Carlos (Madrid-España, 2010/2015). Se unió al Departamento de Ingeniería Eléctrica de la Universidad de las Fuerzas Armadas ESPE en 2002, donde ha sido profesor titular desde 2005. Ha participado en más de diez proyectos de investigación con fondos públicos y dirigido cinco de ellos. Sus principales áreas de intereses en investigación son: procesamiento digital de señales, ciudades inteligentes, sistemas inalámbricos y teoría de aprendizaje automático. 